\title{
Bentonite can decrease ammonia volatilisation losses from poultry litter: laboratory studies
}

\author{
M. R. Redding \\ DAFF, AgriScience Queensland, PO Box 102, Toowoomba, Qld 4350, Australia. \\ Email: matthew.redding@daff.qld.gov.au
}

\begin{abstract}
Ammonia volatilisation from manure materials within poultry sheds can adversely affect production, and also represents a loss of fertiliser value from the spent litter. This study sought to compare the ability of alum and bentonite to decrease volatilisation losses of ammonia from spent poultry litter. An in-vessel volatilisation trial with air flushing, ammonia collection, and ammonia analysis was conducted over 64 days to evaluate the mitigation potential of these two materials. Water-saturated spent litter was incubated at $25^{\circ} \mathrm{C}$ in untreated condition (control) or with three treatments: an industryaccepted rate of alum $\left[4 \% \mathrm{Al}_{2}\left(\mathrm{SO}_{4}\right)_{3} \cdot 18 \mathrm{H}_{2} \mathrm{O}\right.$ by dry mass of litter dry mass; ALUM], air-dry bentonite ( $127 \%$ by dry mass; BENT), or water-saturated bentonite (once again at $127 \%$ by dry mass; SATBENT). A high proportion of the nitrogen contained in the untreated spent litter was volatilised (62\%). Bentonite additions were superior to alum additions at retaining spent litter ammonia (nitrogen losses: 15\%, SATBENT; 34\%, BENT; 54\%, ALUM). Where production considerations favour comparable high rates of bentonite addition (e.g. where the litter is to be re-formulated as a fertiliser), this clay has potential to decrease ammonia volatilisation either in-shed or in spent litter stockpiles or formulated products, without the associated detrimental effect of alum on phosphorus availability.
\end{abstract}

Received 17 October 2012, accepted 23 November 2012, published online 9 April 2013

\section{Introduction}

Volatilisation losses from animal wastes in housed production systems, including from poultry bedding materials, are problematic for several reasons. First, ammonia in shed atmosphere may reach concentrations of concern for the welfare of workers and animals alike (Barrasa et al. 2012), and may decrease productivity (Miles et al. 2011), or resistance to pathogens (Hoerr 2010). Second, this ammonia volatilisation represents a loss of fertiliser value of the spent bedding material, decreasing economic returns or increasing costs of removal for this waste stream.

Housed, intensive poultry production for human consumption is common in industrialised countries. The bedding materials employed for birds include wood shavings and rice hulls, and the birds are fed a controlled ration. Manure, wasted feed, and feathers accumulate in the bedding (Runge et al. 2007), forming a nutrient-rich substrate that may subsequently become a fertiliser source. The costs of appropriate bedding materials and securing an appropriate supply are of concern to poultry producers, including those in Australia and the United States of America. Poultry producers in some locations retain bedding materials for more than one batch of birds, with potential for increasing ammonia volatilisation throughout this period (Chepete et al. 2011).

A range of litter additives have been studied for use in-shed to decrease the volatilisation of ammonia (including alum and bentonite, Sevi et al. 1995; Tymczyna et al. 1995; Li et al. 2008). Bentonite as an additive to bedding material at low rates $(0.4-0.8$ $\mathrm{kg} / \mathrm{m}^{2}$ ) had no effect on atmospheric ammonia concentrations
(Sevi et al. 1995), while at $1.5 \mathrm{~kg} / \mathrm{m}^{2}$ litter ammonia concentration was decreased (Tymczyna et al. 1995). Recent studies have demonstrated that ammonia in poultry litter can readily be sorbed in exchangeable forms by bentonite additions to poultry litter (Redding 2011).

The combined effect of bentonite (as a cation exchanger) and hydrotalcite (as an anion exchanger) as substrates in inorganic fertiliser formulations was introduced by Gillman and Noble (2005) and further explored by Gillman (2011). The addition of these substrates to agricultural wastes such as piggery pond sludge and chicken litter has also been studied (Gillman 2006). Apart from their fertiliser value, these exchange substrate plus manure formulations may be beneficial as soil amendments when added to sandy soils, because each application will result in an increase in clay content, increasing the soil's capacity to retain nutrients and water.

Several other additives (ferric sulfate, alum, and dissolved alum) are already used to decrease ammonia volatilisation and litter-phosphorus (P) loss via runoff or leaching when a litter is land applied as a fertiliser (Li et al. 2008; Warren et al. 2008b). However, because these additives tend to retain $\mathrm{P}$ in forms that may not be plant available they may decrease the fertiliser value of the spent litter (Guo and Song 2009).

In this study, the effect of bentonite on ammonia volatilisation was investigated under controlled conditions as a further step in quantifying and identifying bentonite effects on volatilisation and retention of nitrogen $(\mathrm{N})$ fertiliser value. This study tested two hypotheses that have not previously been addressed in the literature. The first hypothesis was that bentonite addition to litter 
stabilises ammonia- $\mathrm{N}$ against volatilisation losses, and that ammonia retention is significant at the moisture conditions prevalent in close proximity to a leaky drinker where ammonification is likely to be favoured. The second hypothesis was that it is possible to achieve comparable ammonia retention using bentonite to that achieved via recommended rates of alum addition $\left[\mathrm{Al}_{2}\left(\mathrm{SO}_{4}\right)_{3} \cdot 18 \mathrm{H}_{2} \mathrm{O}\right]$ over a period comparable to that of a poultry production batch, or a growing season following fertiliser application.

\section{Materials and methods}

Forty kilograms of litter was collected from a broiler farm in south-east Queensland, 25 days after stock were introduced into the housing (Table 1). The bedding material, $50 \mathrm{~mm}$ depth of hardwood shavings, was transferred to the shed before introduction of the stock as is the normal routine. In order to be representative, the litter sample was collected from below drinkers, around feeders, and from the space between. Immediately after collection, the sample was mixed thoroughly, ground and sieved to pass a 2-mm aperture, and stored in a cold room at $4^{\circ} \mathrm{C}$ until used.

Sodium bentonite, with traces of coal $(<1 \%$; Table 1$)$, was collected from the Ebenezer Coal Mine located at Ipswich (Queensland, as previously described in Redding 2011). This material was prepared by grinding and sieving to pass through a 2-mm aperture, but be retained by a $0.5-\mathrm{mm}$ aperture.

A range of analytical techniques were applied, as described in a previous study (Redding 2011), to characterise these materials. Though the bentonite is the same material previously described, the litter is not.

The litter was analysed as follows (Rayment and Higginson 1992): total-N (Kjeldahl N, method 7A1), $\mathrm{pH}$ (1:5 mass ratio of sample to water), Colwell-P (bicarbonate extractable P, method 9B2), exchangeable bases (washing with solutions of alcohol and glycerol to remove soluble cations preceding an alcoholic

Table 1. Bentonite and spent litter characteristics, reported on an oven-dry basis

\begin{tabular}{|c|c|c|c|}
\hline & Units & $\begin{array}{c}\text { Spent poultry } \\
\text { litter }\end{array}$ & $\begin{array}{c}\text { Bentonite } \\
\text { (Redding 2011) }\end{array}$ \\
\hline Total N & $\%$ & $4.66 \pm 0.01$ & $0.027 \pm 0.001$ \\
\hline Ammonium-N & $\%$ & $0.693 \pm 0.032$ & - \\
\hline Nitrate-N & $\%$ & $<0.03$ & - \\
\hline Total P & $\%$ & $1.69 \pm 0.04$ & $0.018 \pm 0.003$ \\
\hline Bicarbonate P & $\%$ & $0.578 \pm 0.06$ & $0.0004 \pm 0.0002$ \\
\hline Total K & $\%$ & $3.21 \pm 0.11$ & $0.07 \pm 0$ \\
\hline Organic $\mathrm{C}$ & $\%$ & $50.5 \pm 0.82$ & $0.36 \pm 0.03$ \\
\hline Total C & $\%$ & $59.82 \pm 0.44$ & $0.95 \pm 0.11$ \\
\hline Exchangeable $\mathrm{Ca}$ & $\operatorname{cmol}(+) / \mathrm{kg}$ & $18.4 \pm 1.1$ & $15.4 \pm 0.6$ \\
\hline Exchangeable $\mathrm{Mg}$ & $\operatorname{cmol}(+) / \mathrm{kg}$ & $47.5 \pm 2.6$ & $14.9 \pm 0.9$ \\
\hline Exchangeable K & $\operatorname{cmol}(+) / \mathrm{kg}$ & $83.1 \pm 1.9$ & $1.52 \pm 0.04$ \\
\hline Exchangeable $\mathrm{Na}$ & $\operatorname{cmol}(+) / \mathrm{kg}$ & $36.0 \pm 2.3$ & $50.7 \pm 0.8$ \\
\hline ECEC & $\operatorname{cmol}(+) / \mathrm{kg}$ & $185 \pm 8$ & $82.6 \pm 2.3$ \\
\hline Soluble $\mathrm{Ca}$ & $\mathrm{mmol} / \mathrm{kg}$ & $6.04 \pm 0.52$ & $19.8 \pm 0.3$ \\
\hline Soluble Mg & $\mathrm{mmol} / \mathrm{kg}$ & $19.9 \pm 0.5$ & $17.8 \pm 0.2$ \\
\hline Soluble K & $\mathrm{mmol} / \mathrm{kg}$ & $36.2 \pm 2.2$ & $1.53 \pm 0.04$ \\
\hline Soluble $\mathrm{Na}$ & $\mathrm{mmol} / \mathrm{kg}$ & $10.6 \pm 0.6$ & $51.2 \pm 4.6$ \\
\hline $\mathrm{pH}$ & - & $7.85 \pm 0.04$ & - \\
\hline
\end{tabular}

$1 \mathrm{M}$ ammonium chloride extract, $\mathrm{pH} 8.5$; method $15 \mathrm{C} 1$ ), soluble bases (1 M ammonium chloride extract, $\mathrm{pH} 7.0$; method 15A1) and effective cation exchange capacity (the sum of the individual exchangeable cations), total potassium, total carbon (high frequency induction furnace, method 6B2), organic carbon (Walkley and Black 1934), and total P (Crosland et al. 1995).

All water used in these studies was purified to $>18 \mathrm{M} \Omega . \mathrm{cm}$ (MilliQ Academic reverse osmosis unit), and contained no detectable ammonium-N $(<1.1 \mu \mathrm{g} / \mathrm{mL})$.

\section{Ammonium volatilisation from bentonite and alum-treated litters}

Twelve 0.7-L glass jars received $45 \mathrm{~g}$ (oven-dry equivalent) of the homogenised spent litter, and $91 \mathrm{~mL}$ of water, raising the moisture content to saturation and representing conditions in-shed close to a leaky drinker. Treatments were then applied to nine of the jars. Three jars received treatments of alum, amounting to $4 \%$ of the dry litter mass (ALUM). This is approximately equivalent to the in-shed single-batch application rate $\left(244 \mathrm{~g}\right.$ of alum $\left./ \mathrm{m}^{2}\right)$ that has been previously recommended (Shah et al. 2012). Six jars received $57 \mathrm{~g}$ of oven-dry equivalent bentonite, a rate equivalent to that suggested based on cation exchange retention in fertiliser formulation (Redding 2011).

The treatment and litter materials in each jar were then thoroughly mixed. Three of the bentonite treated jars remained in this state (BENT), while additional water was mixed into the remaining three, raising the bentonite + litter mixture to saturation $(205 \%$ moisture content, dry basis; SATBENT treatment). This treatment was included as additions of bentonite to the saturated litter material decreased the free water in the treatment dramatically. The second bentonite treatment better represented the saturated conditions of the untreated litter and ALUM treatment.

A bung with an integrated gas inlet (reaching to just above the surface of the litter mixture) and outlet was fitted to each jar. Instrument grade air was metered through each jar at a rate of $50.3 \pm 3.2 \mathrm{~mL} / \mathrm{min}$ (mean \pm standard deviation) via a manifold and needle valves, with flow rates being measured and corrected 5 days each week. Outlet gas from each jar was directed through two 75-mL glass impingers (in series), each filled with $0.25 \mathrm{M} \mathrm{H}_{2} \mathrm{SO}_{4}$.

The impinger solutions were replaced with fresh $0.25 \mathrm{M}$ $\mathrm{H}_{2} \mathrm{SO}_{4}$ at 7, 21, 33, 50, and 64 days after commencement. The solutions from the impingers were analysed via steam distillation for entrained ammonia (Mulvaney 1996; $20 \mathrm{~mL}$ of saturated $\mathrm{NaOH}$ solution replaced $\mathrm{MgO}$ in the process).

The instrument grade air was also tested for ammonia content via the impinger and steam distillation process. Treatment and litter moistures were maintained throughout the experiment, which was conducted at $25^{\circ} \mathrm{C}$.

The experiment was halted after 64 days of flushing with instrument grade air, and the $\mathrm{pH}$ of the treated spent litter samples analysed.

\section{Statistical analyses}

Three statistical techniques were employed throughout the trial: non-linear regression was conducted using analysis of 
repeated-measures (REML procedure), and one-way analysis of variance (ANOVA procedure) using Genstat (VSN International 2011).

\section{Results and discussion}

After 64 days of flushing with instrument grade air, total ammonia volatilisation from water-saturated untreated litter reached a mean value of $28.9 \mathrm{mg}$ of $\mathrm{NH}_{3}-\mathrm{N} /(\mathrm{g}$ of litter) (Fig. 1), or $\sim 62 \%$ of the total $\mathrm{N}$ contained in the litter (Table 1). This loss is both a potential air-quality concern and a very significant loss of fertiliser value, despite the low air exchange rate applied ( $\sim 4$ volume exchanges each hour) in comparison to shed ventilation rates (maximum ventilation rates should exceed 60 volume exchanges per hour, CobbVantress 2008).

In saturated and unsaturated conditions, bentonite additions significantly decreased ammonia volatilisation, $(P<0.05$, ANOVA on the cumulative results, analysis of repeatedmeasures, order 1 antedependence), probably due to bentonite's capacity to adsorb ammonia on exchange sites, as observed in earlier experiments (Redding 2011). The decrease due to the bentonite treatments was significantly greater than that resulting from alum addition $(P<0.05)$. The greatest decrease in ammonia volatilisation occurred under saturated conditions (76\% decrease; SATBENT; unsaturated $45 \%$ decrease, BENT; Fig. 1). It is likely that the higher moisture content aids diffusion of ammonium ions to exchange sites, though there may also be a $\mathrm{pH}$ effect related to waterlogging ( $\mathrm{pH}$ following experiment, mean \pm standard deviation: litter, $8.25 \pm 0.17$; BENT, $8.04 \pm 0.28$; SATBENT, $7.62 \pm 0.02$, significantly different to litter, $P<0.05$; ALUM, $8.07 \pm 0.08$ ). Soils under waterlogged conditions often tend to approach neutral $\mathrm{pH}$ (Ponnamperuma 1972), as did this litter system.

The $\mathrm{pH}$ of these litter treatments is sufficient for $2-10 \%$ of the $\mathrm{NH}_{3}-\mathrm{N}$ and $\mathrm{NH}_{4}{ }^{+}-\mathrm{N}$ contained in solution to exist as $\mathrm{NH}_{3}(\log$ to base 10 of the activity equilibrium constant is 9.28 ; Lindsay 1979). This $\mathrm{NH}_{3}$ is vulnerable to volatilisation and will not be retained by cation exchange. In addition to any water-logging

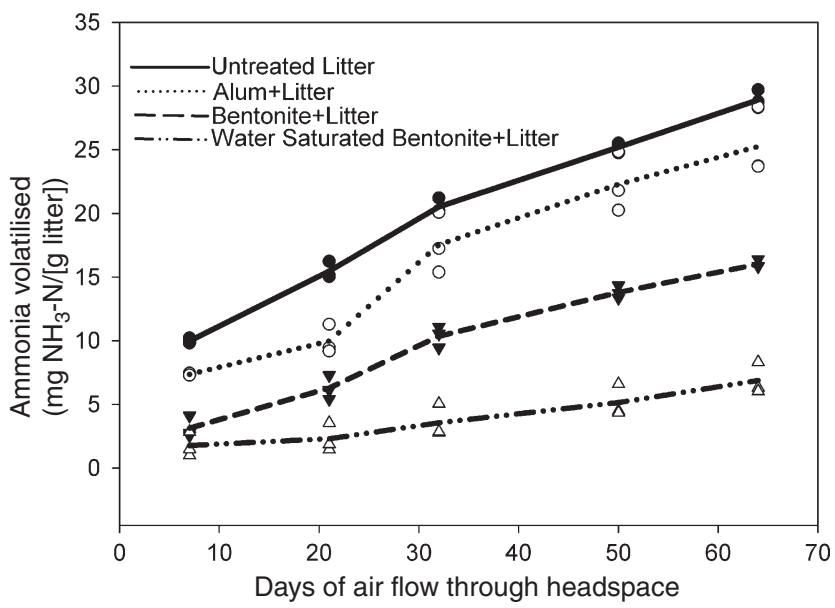

Fig. 1. Cumulative ammonia volatilisation from the treated and untreated litter with continued air flow. Each treatment is significantly different from the other $(P<0.05$, analysis of repeated measures). effect, the saturated conditions maintained for the SATBENT treatment provide a greater volume of water to dissolve ammonium ions and result in a lower $\mathrm{pH}$. Consequently, only $2 \%$ of the $\mathrm{NH}_{3}+\mathrm{NH}_{4}{ }^{+}$nitrogen in solution exists as $\mathrm{NH}_{3}$. While wet conditions may favour retention of $\mathrm{NH}_{4}{ }^{+}$, these conditions also favour the microbial process of formation of ammonium from organic $\mathrm{N}$ forms (ammonification). Therefore, bentonite's ammonium adsorption behaviour may be quite suitable for this application.

The litter chosen for this study was challenging with regard to ammonia volatilisation, due to its high initial $\mathrm{pH}(7.85)$. Australian spent litter tends to be slightly acidic, with $\mathrm{pH}$ ranging from 5.8 to 8.0 (Dorahy and Dorahy 2008). For acid spent litter materials, further improvements in ammonium retention may be achieved by acidifying the bentonite added to the bedding material - though the advantages and disadvantages of this approach were not investigated.

Alum additions resulted in significantly decreased ammonia emission throughout the trial $(13 \%$ decrease in cumulative $\mathrm{N}$ losses; Fig. 1; $P<0.05$, ANOVA on the cumulative results, analysis of repeated-measures, order 1 antedependence), though this effect appeared to decrease after the first 3 weeks of application. Alum causes ammonia to be retained by acidifying the poultry litter, and since no effective acidification in the ALUM treatment was observed after 64 days $(P<0.05$, ANOVA), it appears that this effect was shorter lived than the experimental period or not effectively induced. Higher rates or multiple applications may be required.

The rates of application of bentonite in this trial were large ( $\sim 127 \%$ of the dry litter mass), with a view to the subsequent manufacture of a fertiliser product from the mixture (Gillman 2007). Such heavy applications of bentonite may well be uneconomic where a significant return on the sale or use of the spent litter product is not achieved. Alum addition to spent litter is an established practice to decrease ammonia volatilisation and $\mathrm{P}$ losses due to runoff or leaching after land application. However, these additions may be detrimental to the agronomic $\mathrm{P}$ value of the spent litter (Warren et al. 2008a; Guo and Song 2009). Conventional alum additions are not, therefore, a tool to return maximum fertiliser value from spent litter, and the cost of application must be justified on another basis. For this reason the alum was applied at recommended rates. Higher rates of application are sometimes recommended or applied where a single application of litter substrate is used for bedding multiple batches of birds (Shah et al. 2012), or in studies specifically seeking to decrease P availability (e.g. Moore and Miller 1994).

Application of bentonite may prevent $\mathrm{N}$ losses in- or postshed, possibly providing a more effective input material for a fertiliser product (potentially with additional nutrient additions to create a nutrient-balanced high-value product; Gillman 2006). In-shed application may provide a production benefit (e.g. higher growth rates due to decreased atmospheric ammonia concentrations, and decreased expenditure on other bedding materials). Such a benefit would serve to decrease the production cost of a high efficiency bentonite + spent litter fertiliser from the waste material. The combination of a potential in-shed production benefit and increased returns from the fertiliser value may outweigh the benefits from using alum - a 
treatment material that may be detrimental to fertiliser value. Further research considering production, welfare, and agronomic issues is required before proceeding with this application of bentonite. The welfare and production effects of using bentonite in poultry bedding material at a small poultry-house scale are currently being investigated in a related collaborative study (Walkden-Brown et al. 2013).

\section{Conclusions}

This study has shown that $\mathrm{N}$ losses due to volatilisation from the spent litter amounted to $62 \%$ of total $\mathrm{N}$ after 64 days representing both a potential poultry production concern and loss of fertiliser value. Bentonite additions to spent litter at a rate appropriate for fertiliser formulation (treatment $127 \%$ of the dry mass; $15 \%$ loss of $\mathrm{N}$ in water-saturated conditions, $34 \%$ in moist conditions) retained more ammonia than alum additions at a recommended rate (treatment $4 \%$ of dry mass; $54 \%$ loss of $\mathrm{N}$ in water-saturated conditions).

\section{Acknowledgements}

Mr L. Pott and Mr J. Devereux provided considerable assistance in the day-today operation of this study, while an anonymous reviewer provided valuable comment on the manuscript. This research was conducted within the Poultry $\mathrm{CRC}$, established and supported under the Australian Government's Cooperative Research Centres Program.

\section{References}

Barrasa M, Lamosa S, Fernandez MD, Fernandez E (2012) Occupational exposure to carbon dioxide, ammonia and hydrogen sulphide on livestock farms in north-west Spain. Annals of Agricultural and Environmental Medicine 19, 17-24.

Chepete JH, Xin HW, Li H (2011) Ammonia emissions of laying-hen manure as affected by accumulation time. Japanese Poultry Science 48, 133-138. doi:10.2141/jpsa.010087

Cobb-Vantress (2008) 'Broiler management guide.' (Cobb-Vantress Inc.: Siloam Springs, AR) Available at http://www.cobb-vantress.com/ contactus/brochures/Broiler_Mgmt_Guide_2008.pdf [Verified 14 December 2012]

Crosland AR, Zhao FJ, McGrath SP, Lane PW (1995) Comparison of aquaregia digestion with sodium-carbonate fusion for the determination of total phosphorus in soils by inductively-coupled plasma-atomic emissionspectroscopy (icp). Communications in Soil Science and Plant Analysis 26, 1357-1368. doi:10.1080/00103629509369377

Dorahy CG, Dorahy CM (2008) 'Understanding the fertiliser value of poultry litter.' (Rural Industries Research and Development Corporation: Kingston, ACT)

Gillman GP (2006) Converting feedlot waste to fertilizer using charged clays: environmental and economic benefits. Environmental Quality Management 16, 73-80. doi:10.1002/tqem.20122

Gillman GP (2007) An analytical tool for understanding the properties and behaviour of variable charge soils. Australian Journal of Soil Research 45, 83-90. doi:10.1071/SR06117

Gillman GP (2011) Charged clays: an environmental solution. Applied Clay Science 53, 361-365. doi:10.1016/j.clay.2010.06.025

Gillman G, Noble A (2005) Environmentally manageable fertilizers: a new approach. Environmental Quality Management 15, 59-70. doi:10.1002/ tqem. 20081
Guo M, Song W (2009) Nutrient value of alum-treated poultry litter for land application. Poultry Science 88, 1782-1792. doi:10.3382/ps.200800404

Hoerr FJ (2010) Clinical aspects of immunosuppression in poultry. Avian Diseases 54, 2-15. doi:10.1637/8909-043009-Review.1

Li H, Xin H, Liang Y, Burns RT (2008) Reduction of ammonia emissions from stored laying hen manure through topical application of zeolite, Al+ Clear, Ferix-3, or poultry litter treatment. Journal of Applied Poultry Research 17, 421-431. doi:10.3382/japr.2007-00076

Lindsay WL (1979) 'Chemical equilibria in soils.' (John Wiley and Sons: New York)

Miles DM, Rowe DE, Cathcart TC (2011) High litter moisture content suppresses litter ammonia volatilization. Poultry Science 90 1397-1405. doi:10.3382/ps.2010-01114

Moore PA Jr, Miller DM (1994) Decreasing phosphorus solubility in poultry litter with aluminum, calcium, and iron amendments. Journal of Environmental Quality 23, 325-330.

Mulvaney RL (1996) Nitrogen-inorganic forms. In 'Methods of soil analysis. Part 3. Chemical methods'. (Eds DL Sparks, AL Page, PA Helmke, RH Loeppert, PN Soltanpour, MA Tabatabai, CT Johnston, ME Sumner) pp. 1123-1184. (Soil Science Society of America, Inc.: Madison, WI)

Ponnamperuma FN (1972) The chemistry of submerged soils. Advances in Agronomy 24, 29-96. doi:10.1016/S0065-2113(08)60633-1

Rayment GE, Higginson FR (1992) 'Australian laboratory handbook of soil and water chemical methods.' (Inkata Press: Melbourne) 330 pp.

Redding MR (2011) Bentonites and layered double hydroxides can decrease nutrient losses from spent poultry litter. Applied Clay Science 52, 20-26. doi:10.1016/j.clay.2011.01.016

Runge GA, Blackall PJ, Casey KD (2007) 'Chicken litter: issues associated with sourcing and use.' (Rural Industries Research and Development Corporation: Kingston, ACT)

Sevi A, Muscio A, Campanaro G, Dantone D (1995) Environmental control in animal houses: effect of bentonite treatment of litter on air quality and the performance of broilers. Archivio Veterinario Italiano 46, 113-121.

Shah SA, Westerman P, Parsons J (2012) Poultry litter amendments. Cooperative Extension System, United States. Available at http://www. extension.org/sites/default/files/Litter\%20Amendments\%20FINAL.pdf [Verified 14 December 2012]

Tymczyna L, Majewski T, Podgorski W, Polonis A (1995) Effect of adding natural aluminosilicate (bentonite) on sanitary conditions and growth of broiler chickens. Roczniki Naukowe Zootechniki 22, 371-381.

VSN International (2011) 'GENSTAT for Windows.' 14th edn. (VSN International: Hemel Hempstead, UK)

Walkden-Brown S, Islam A, Van Den Heuvel A, Cressman M, Redding M (2013) Effects of various additives to reused broiler litter on ammonia production, chicken welfare and performance. In 'Proceeds of the Australian poultry science symposium. Vol. 24'. (University of Sydney: Sydney) in press.

Walkley A, Black I (1934) An examination of the Degtjareff method for determining soil organic matter and a proposed modification of the chromic acid titration method. Soil Science 37, 29-38. doi:10.1097/ 00010694-193401000-00003

Warren JG, Penn CJ, McGrath JM, Sistani K (2008a) The impact of alum addition on organic $P$ transformations in poultry litter and litter-amended soil. Journal of Environmental Quality 37, 469-476. doi:10.2134/ jeq2007.0239

Warren JG, Phillips SB, Mullins GL (2008b) Impact of soil type and application rate on the availability of $\mathrm{P}$ applied as alum-treated poultry litter. Communications in Soil Science and Plant Analysis 39, 2515-2533. doi:10.1080/00103620802358441 